\title{
Society's Willingness to Pay for Certified Dry Firewood Energy in Chile
}

\author{
Leidy Y. García, Arcadio A. Cerda*, Rocio del P. Lagos, Patricio I. Muñoz and \\ Monserrat Muñoz
}

Faculty of Economics and Business, Universidad de Talca, Talca, Chile

Introduction: Air pollution is present in most cities in Chile due to smoke produced from firewood, as happened in many developing countries, generating various health problems among the population. This situation is especially prevalent in all cities in central and southern Chile. To mitigate it, the government implemented several measures, among which are the promotion of the use of certified dry firewood and hourly restrictions on the use of wood-burning stoves for heating according to the peak emissions of particulate matter.

\section{OPEN ACCESS}

Edited by:

Biagio Fernando Giannetti,

Paulista University, Brazil

Reviewed by: Christian Oltra

Centro de Investigaciones Energéticas, Medioambientales y Tecnológicas, Spain Muhammad Mohsin, Jiangsu University, China Alejandra Schueftan,

Forest Institute, Chile

*Correspondence: Arcadio A. Cerda acerda@utalca.cl

Specialty section: This article was submitted to Sustainable Energy Systems and a section of the journal Frontiers in Energy Research

Received: 08 March 2021 Accepted: 18 May 2021 Published: 07 June 2021

Citation:

García LY, Cerda AA, Lagos RdelP, Muñoz Pl and Muñoz M (2021) Society's Willingness to Pay for Certified Dry Firewood Energy in Chile. Front. Energy Res. 9:676654. doi: 10.3389/fenrg.2021.676654
Objective: The objective of this study was to determine the willingness to pay for certified dry firewood as a means of reducing environmental restrictions on the use of woodburning stoves to heat households.

Materials and methods: The study used a non-market valuation, specifically contingent valuation, method using a double-bounded dichotomous choice format with the estimation of biprobit econometric models.

Results: The results showed that the average individual was willing to pay 12 USD, and extrapolating that to the local population's willingness to pay yielded an economic value of 3,415,140 USD, which to a certain extent represents the valuation of air pollution damage.

Conclusion: Our results showed that people positively valued the use of dry firewood as a payment vehicle to improve air quality and thereby reduce restrictions on the use of certified dry firewood for heating. Therefore, complementary environmental policy measures should be continued to address the problem of air pollution in both the short and long term.

Keywords: air quality, health, contingent valuation, pollution, wood burning energy

\section{INTRODUCTION}

Air pollution is present in most cities, causing various health problems among the population, especially in developing countries (Johnson and Takama, 2012; Amegah et al., 2014; Carvalho et al., 2018; Bjørner et al., 2019; Quinteros et al., 2019; Sinha and Kumar, 2019; Fleisch et al., 2020; Nduka, 2021). Evidence indicates that atmospheric pollutants are responsible for contributing to the increase in overall mortality (Ostro et al., 1996; Romieu et al., 2012). This makes air pollution significant in determining the quality of life of small children, the elderly, and patients with cardiovascular/ respiratory diseases (Arnetz et al., 2020). Although there are different sources of air pollution (Hime 
et al., 2018; Shi et al., 2019; Bangar et al., 2021), this study will focus on pollution from the use of caloric energy (firewood) for heating. Residential wood-burning is estimated to cause 29,000 premature deaths in Europe and North America annually (Amegah et al., 2014; Carvalho et al., 2018; Bjørner et al., 2019; Quinteros et al., 2019; Fleisch et al., 2020). Chile is no exception, as air pollution is one of its main problems (Mardones and Cornejo, 2020; Mardones, 2021). According to the Chilean Ministry of the Environment (2017), air pollution is the main environmental problem in the country, and $38.4 \%$ of Chileans declare this as a main problem. Of this percentage, $32.7 \%$ claim it is due to pollution from chimneys and wood-burning stoves, like in many cities around the world, while the remaining $8 \%$ attribute it to other factors.

According to the IQAir World Air Quality Report 2020, Chile has 12 cities among the 15 most polluted cities in South America (IQAir, 2020). In Chile, the period with the most pollution is between June and September due to the low temperatures, which increases the use of fuels. The city of Talca, with a population of more than 250,000 , is a very representative city. It was declared an area saturated by particulate matter due to the high pollution level, like several other cities (Cerda et al., 2010; Quinteros et al., 2019). This problem has grown in recent years, causing increased levels of breathable particulate matter, PM10 and PM2.5, which is the most harmful to people's health (García and Álvarez, 2013; Ministerio de Medio Ambiente, 2017).

A direct way to contribute to the reduction of particulate matter is to prohibit the use of firewood as the main source of heat; because if nothing is burned, there are no particles in the air. However, this solution is difficult to implement. Its use is associated with energy poverty in Chile, about which there is a complex reality (Villalobos et al., 2021), because firewood is one of the fuels to which the largest proportion of the population has access and it is highly polluting when wet (Reyes et al., 2019). For this reason, the Ministry of the Environment of Chile and Ministry of Housing have adopted various policies to reduce pollution from the use of firewood (Jorquera, 2021). The first is a strategy to replace old stoves, which are more polluting, with new ones with lower emissions and better energy efficiency (Boso et al., 2019; Mardones, 2021). The second policy consists of subsidies to improve the thermal insulation of houses (Schueftan et al., 2016; Martinez-Soto et al., 2020). And the third is the prohibition of the use of wood stoves in periods with high levels of pollution. For example, for the Management of Critical Episodes, the environmental authority monitors particulate matter measurement stations (Mardones and Cornejo, 2020; Jorquera, 2021; Mardones, 2021). And based on these, it can give three types of notice: 1 . Warning, the restriction of use is from 6:00 to $11: 59 \mathrm{pm} ; 2$. Pre-emergency, restriction is from $6 \mathrm{pm}$ to $6 \mathrm{am}$; and 3. Emergency restriction, which is all day. For this, there is a remote inspection system for the measurement stations plus inspectors that monitor and fine houses for not complying with the regulations (Jorquera, 2021).

It should be noted that of the policy measures indicated above, there is evidence in the scientific literature related to the impact of the replacement of heaters and housing insulation subsidies (Schueftan et al., 2016; Martinez-Soto et al., 2020; Mardones,
2021). However, there is scarce recent evidence on the effectiveness of the prohibition of wet firewood, and more relevant still, on consumers' assessment of certified dry firewood, which affects the effectiveness of the measure. Furthermore, there is little scientific evidence on firewood certification programs, both in the national and international literature (Cai and Aguilar, 2013; Vásquez et al., 2020).

Specifically, for efforts to reduce air pollution by using dry firewood to be effective, it is necessary that not only are there clear and adequate standards in a certification program for dry firewood (production), but that consumers value their consumption and potential benefits. As indicated by Vasquez (2020), it is necessary to study consumer preferences regarding certified dry firewood, which are manifested in their willingness to pay for this type of energy, a subject on which literature is scarce (Vásquez et al., 2020). Palmieri et al. (2020) mentioned that more research is required on consumers' willingness to pay a higher price for certified firewood.

This is worrisome from environmental and health perspectives, because despite the regulations and information provided by the authority, people continue to use damp firewood to heat their homes due to its lower price compared to alternative heating sources, and this generates more air pollution (Jaime et al., 2020). Therefore, it is important to study people's willingness to pay for dry firewood to improve air quality. This will provide relevant information for the formulation of public policies on the use of clean energies, which will help us care for the environment and reduce pollution's impact on health. Determining the willingness to pay requires assessing the perceived individual and social benefits (Freeman et al., 2014a) of the use of dry firewood. Hence, the following questions arise: How much would people be willing to pay for certified dry firewood to reduce pollution? And how much would they be willing to pay for similar but much less polluting heating while avoiding further restrictions?

The primary objective of this study was to determine the willingness to pay to avoid further time restrictions on using wood-burning stoves in Chile. The payment vehicle used was the additional price that individuals would pay to buy dry wood. To do this, we used the contingent valuation method, which makes it possible to construct a hypothetical market using a doublebounded dichotomous choice format (Vásquez et al., 2007).

\section{METHODS}

Both descriptive statistics and quantitative methods were used. The quantitative methods consisted of a double-bounded contingent valuation model, which allowed us to estimate the willingness to pay (WTP) to avoid additional restrictions on using wood-burning stoves for heating.

\section{Conceptual Framework}

Economic theory values natural resources and environmental services; this is based on the subjective preferences of the individuals that comprise a society, i.e., the idea is to reach maximum social well-being at the lowest possible cost, which 
involves assigning a price or monetary value to natural resources and environmental services, since environmental services have value for society. According to different authors, the methods of economic valuation have been classified into three categories: direct valuation, indirect valuation, and contingent valuation. The third is what is addressed here (Dixon and Hufschmidt, 1986; James, 1994; Haab and McConnell, 2002; Segerson, 2017; Streimikiene et al., 2019; Cuccia, 2020).

The contingent valuation method is one of the standard approaches for valuing non-traded resources in the market, such as the quality of the environment, with high utilization in analyses of public policies (Lee and Heo, 2016; Cuccia, 2020). It seeks to measure in monetary units changes in the level of people's well-being due to an increase or decrease in the quality or amount of a good or service. This measurement is expressed as the WTP, which consists of the monetary value of the difference in consumer surplus before and after a specific product attribute is incorporated or modified. In the contingent valuation method, the question format used is fundamental to obtaining the WTP, since it plays an important role in the hypothetical market where the supply is represented by the interviewer and the demand by the respondent (García and Álvarez, 2013).

According to experts, the suitable model to use is the dichotomous model (Arrow et al., 1993; Fattahi Ardakani et al., 2017), where the respondent is asked if they would pay a certain amount of money for a good or service, chosen at random from a range of values. According to Hanemann (1984), this model has an important assumption that the individual knows their utility function with certainty. Another benefit of this model is that the respondent is faced with a known situation, buying a good subject to an income restriction where the price of the good is fixed, which makes it possible to obtain lower rejection and prediction rates (Freeman et al., 2014b).

Two forms of the dichotomous model can be distinguished. The single-bounded dichotomous model consists of asking the respondent if they are willing or not to pay a fixed amount for a good or for a change in the characteristics of the good. The double-bounded dichotomous model consists of adding a second question, also dichotomous, with a higher value if the response is "yes" to the first question, or a lower value if the response is "no" to the first question. The double-bounded dichotomous model is the most suitable, allowing for better accuracy of the variancecovariance matrix of the coefficients included, which makes it possible to obtain smaller confidence intervals in comparison with the single-bounded dichotomous model (Hanemann et al., 1991; Oerlemans et al., 2016).

\section{Econometric Framework}

Hanemann's model (Hanemann, 1984; Xie et al., 2019) is defined as the difference in the indirect utility function and is of the type $u_{j}=v_{j}\left(P, Y: q_{j}\right)+\varepsilon_{j}$ with $j=0$ for the starting point, $j=1$ for the end point (after the air quality has improved), $Y=$ Income, $P=$ Price of the goods, $q=$ Environmental quality and/or socioeconomic characteristics of the individuals, and $\varepsilon=$ Random mean error 0 . The compensating variation method assumes that utility functions have components that the investigator does not know, generating a stochastic structure of the utility function. This random component can incorporate characteristics of the individual and the alternatives being assessed. For this, the indirect utility function is a random variable with a probability distribution for the parameters and with means that depend on the observable characteristics of the individual (Vásquez et al., 2007).

Individuals have a maximum WTP to reduce air pollution, and the restrictions on using wood-burning stoves as a source of heat, through the purchase of certified dry firewood, is represented by $C$, the value of which is not observable; therefore, a payment vector $b_{t}$ is used with the respondents being presented with different payment options. The values of $b_{t}$ and $C$ do not agree, so with the payment vector we can get the probability of reaching a positive response, which is expressed as $\eta \equiv \varepsilon_{0}-\varepsilon_{1}$; therefore, $\Delta v \equiv v_{1}\left(P, Y-b_{t} ; q_{1}\right)-v_{0}\left(P, Y ; q_{0}\right)$. Finally, we have the expression $\operatorname{Prob}(y e s)=\operatorname{Prob}(\Delta v>\eta)=F_{\eta}(\Delta v)$, where $F_{\eta}$ is the distribution function of $\eta$.

In this case, we used the double-bounded dichotomous choice model. To obtain the payment vectors to be used in the model, we surveyed 100 people, who were asked openly about their willingness to pay to reduce the restrictions on the use of heating stoves via the purchase of dry wood. With these data, the payment vector was constructed, consisting of 10 values, which were obtained by minimizing the mean square error of the additional WTP for certified dry firewood of 100 individuals (Cerda et al., 2014). The method used to estimate the model was a bivariate probit method (Loomis and Ekstrand, 1997; Obeng and Aguilar, 2021). This method estimates the model parameters by maximizing the likelihood function with respect to the model parameters, finding the parameter values that maximize the probability of finding the answers obtained in the applied survey (Cooper, 1993; Cooper and Hellerstein, 1994; Bateman and Willis, 2002).

\section{The Monetary Measurement and Payment Vehicle}

In terms of the economic measurement of well-being, there are several ways to find a monetary value for the changes in wellbeing generated in individuals due to transformations; in this case, due to the use or non-use of certified dry firewood. We used the compensating variation method, which consists of the maximum amount of money that an individual is willing to pay to be able to choose a favorable change in their well-being; it is also considered the minimum amount of money that an individual is willing to accept to choose an unfavorable end point. On the other hand, the equivalent variation is the maximum amount of money that an individual is willing to pay for the possibility of not choosing a change that is unfavorable for their well-being, or it can also be considered as the minimum amount of money a person is willing to accept for the possibility of forgoing a change that is favorable to their well-being. $\mathrm{C}+$ is considered the average of the maximum willing to pay $\mathrm{C}$, and $\mathrm{C}^{\star}$ is the median of the maximum willingness to pay $C$, i.e., the amount of money that causes people to be indifferent to a choice between two alternatives. 
Studies show that it is important to define the payment vehicles, understanding this as the price associated with an environmental improvement (Ivehammar, 2009; Oerlemans et al., 2016). The payment vehicle must be credible to the person; in other words, they must believe that if they want access to an improvement, they must pay for it. In our case, given that people tend to burn moist wood for heat, we used the higher price of buying dry wood, recognized as the best way to reduce air pollution for low-income people or when there are no other close substitutes available, technically and economically.

\section{The Questionnaire}

The questionnaire consisted of 11 sections with a total of 90 questions, including the informed consent question. We can group these into five parts: 1) questions associated with general and normal social knowledge about the environment $(18)$; 2) questions associated with people's perception of the environmental responsibility of the public, private, and community sectors $(21)$; 3 ) questions about attitude, behavior, and environmental satisfaction $(25)$; 4) questions about their willingness to pay and reasons for refusal (17); and 5) questions about the socio-economic characteristics of the sample (8). For this study, we used mainly questions from parts 4 and 5 .

\section{Sampling Procedure and bid Vector Estimation}

The data were obtained in the city of Talca via a face-to-face survey. The sample required for this type of study considering the study population $(227,674$ individuals), maximum variance, a 95\% confidence level, and a standard error of 5\% was 383 individuals. To reduce the sampling error term to $4.3 \%, 503$ individuals 18 years old or older, distributed proportionally by socioeconomic level, were surveyed, as presented in Table 1.

Table 1 also presents the subsample per bid value and the initial, lower, and upper bid values per socioeconomic level. The percentage values under the column "socioeconomic level" show the representativeness of each socioeconomic level in the city. The first two columns were obtained by minimizing the mean square error of the willingness to pay for certified dry firewood of 100 individuals, limiting the bid to 10 values. The values required to construct the bid vector were obtained from an open-ended question, which means that the mentioned individuals stated an additional monetary value they were willing to pay for a given situation or environmental change. In our study, the contingent or hypothetical situation was presented to each person as follows:

"By using certified dry firewood, you will have direct benefits, such as higher combustion efficiency and double heat generation, and indirect benefits, since air pollution decreases by approximately $70 \%$. Consequently, this will reduce respiratory illnesses significantly.

People, even knowing how harmful the use of wet wood is, do not stop using it, which causes the city of Talca to have high levels of air pollution. Given this scenario, the authorities implemented hourly restrictions depending on the level of contamination, which are a) Environmental Warning (6:00-11:59 pm), b)
Environmental Pre-emergency (6:00 pm-6:00 am), and c) Environmental Emergency $(24 \mathrm{~h})$. For example, between January and July of this year there have been 45 episodes of time restriction and 69 days exceeded the norm established by the Ministry of the Environment.

Due to the seriousness of the matter, it is being considered to extend the time restrictions; that is, in case of Environmental Warning, extend the restriction by six additional hours per day, as well as in the Environmental Pre-emergency condition. In the case of Environmental Emergency, it will be maintained at $24 \mathrm{~h}$ as is already established. All of this is to combat the emissions of particulate matter in the air, and in this way reduce respiratory illnesses.

Given this situation, we want to know how much you are willing to pay for the use of certified dry firewood to reduce air pollution by avoiding the extension of six (6) additional hours and the number of days with time restrictions in the city of Talca."

Additionally, before introducing the hypothetical market to the respondents, they were advised that they should consider their preferences, income levels, and substitutes before indicating their willingness to pay. The same hypothetical situation was presented to those individuals who were willing to pay for certified dry firewood in the final sample. However, they did not respond to an open-ended question in this case. As for prices, we used the bid vector randomly and in proportion to assure representativeness for each socioeconomic level.

Therefore, the question was as follows: "Given this situation, we want to know if you are willing to pay 'Initial bid value,' for the use of certified dry firewood, to reduce air pollution by avoiding the extension of six (6) additional hours and the number of days with time restriction in the city of Talca." If an individual said Yes, an upper bid (bidu) value was offered, and if they said no, a lower bid ( $b i d l$ ) value or bid was offered, as showed in Table 1. The use of this kind of elicitation procedure (single or double-bounded dichotomic format), instead of an open-ended question format, was because the latter has several short-comings. For example, people lack an initial reference price. Moreover, generally, in actual markets, people face prices but do not provide them. Additionally, in statistical terms, the double-bound estimator is more efficient than the single-bound one (Hanemann et al., 1991; Kanninen, 1993).

\section{RESULTS}

\section{Sample Description}

Of the total sample, 101 individuals did not use wood for heating and cooking (20\%). The remaining 402 individuals (80\%) used firewood, with only $1 \%$ using certified dry firewood. Of the individuals who used firewood, $22.3 \%$ were not willing to pay for certified dry firewood. The most common reasons for this were "I do not have enough money to pay for certified dry firewood," "Those who pollute must pay," "I do not think the rest are willing to pay for certified dry firewood," "Using certified dry wood is not enough to decontaminate the air," and "The municipality should take care of decontaminating the air" (Figure 1). In selecting the 
TABLE 1 | Size and range of payment vector according to subsamples.

\begin{tabular}{|c|c|c|c|c|c|c|c|c|}
\hline \multirow[b]{2}{*}{$\begin{array}{l}\text { Sub- } \\
\text { sample } \\
\text { per bid }\end{array}$} & \multicolumn{3}{|c|}{ Bid values } & \multicolumn{5}{|c|}{ Socioeconomic level } \\
\hline & $\begin{array}{c}\text { Initial } \\
\text { bid (bidi) }\end{array}$ & $\begin{array}{l}\text { Lower } \\
\text { bid (bidl) }\end{array}$ & $\begin{array}{c}\text { Upper } \\
\text { bid (bidu) }\end{array}$ & $\begin{array}{c}\text { High } \\
\text { income }\end{array}$ & $\begin{array}{l}\text { Middle- } \\
\text { high } \\
\text { income }\end{array}$ & $\begin{array}{l}\text { Middle } \\
\text { income }\end{array}$ & $\begin{array}{l}\text { Middle-low- } \\
\text { income }\end{array}$ & $\begin{array}{l}\text { Low- } \\
\text { income }\end{array}$ \\
\hline 32 & $\$ 1,064$ & $\$ 532$ & $\$ 1,596$ & 3 & 5 & 8 & 11 & 5 \\
\hline 67 & $\$ 2,466$ & $\$ 1,233$ & $\$ 3,699$ & 4 & 10 & 18 & 24 & 11 \\
\hline 55 & $\$ 3,384$ & $\$ 1,692$ & $\$ 5,076$ & 3 & 8 & 15 & 20 & 9 \\
\hline 48 & $\$ 5,427$ & $\$ 2,714$ & $\$ 8,141$ & 3 & 7 & 13 & 17 & 8 \\
\hline 50 & $\$ 6,089$ & $\$ 3,045$ & $\$ 9,134$ & 3 & 8 & 13 & 18 & 8 \\
\hline 55 & $\$ 6,828$ & $\$ 3,414$ & $\$ 10,242$ & 3 & 8 & 15 & 20 & 9 \\
\hline 67 & $\$ 7,747$ & $\$ 3,874$ & $\$ 11,621$ & 4 & 10 & 18 & 24 & 11 \\
\hline 31 & $\$ 9,149$ & $\$ 4,575$ & $\$ 13,724$ & 2 & 5 & 8 & 11 & 5 \\
\hline
\end{tabular}

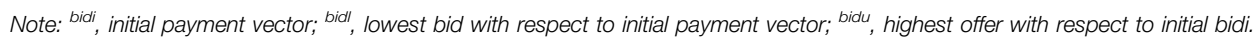

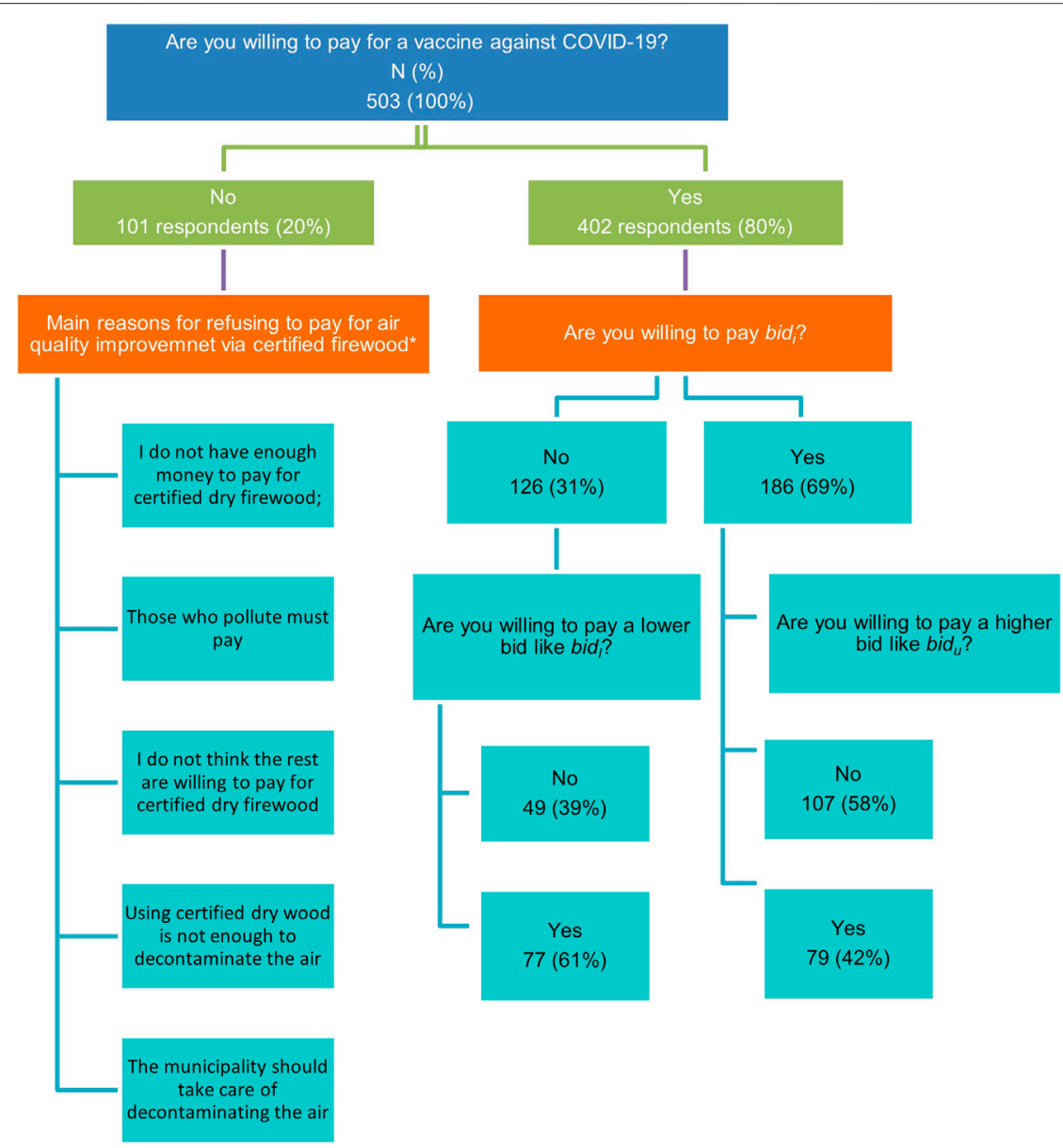

FIGURE 1 | Sample distribution of willingness to pay and refusal reason frequencies. Note: bid $_{i}=$ initial payment vector, bid $=$ lowest bid with respect to initial payment vector, and bid $_{u}=$ highest bid with respect to initial bidi, for $\mathrm{i}=1$ to 10 (quantity of offers). See the values of the bids and sampling distribution in Table $\mathbf{1}$. Additional, respondents (101) could choose more than one option when rejecting willingness to pay (WTP). 
reasons, individuals had the opportunity to select more than one reason from a total of 10 possibilities. All the items mentioned above were chosen by $60 \%$ or more of the total individuals who were not willing to pay for certified firewood, i.e., they were not willing to pay to avoid environmental restrictions.

A total of 503 surveys were conducted in the city of Talca. Of the total sample, $50.5 \%$ were female, which is equivalent to 254 people, and $49.5 \%$ were male, equivalent to 249 people. It was observed that more than $62 \%$ of the individuals surveyed were between 25 and 54 years old. In total, 59\% had an income level between 225 and 1,248 United States dollars (Table 2).

Of the people who did have a stove/wood stove and were willing to pay an additional amount for the use of certified dry firewood, $45.5 \%$ paid $45-52$ United States dollars per cubic meter of firewood, followed by $35.6 \%$ paid 38-44 United States dollars in the last winter season. On average, the price paid by respondents in the city of Talca per cubic meter of firewood was 46.4 United States dollars. Most people in Talca used five cubic meters of firewood annually ( $25 \%$ of the total sample), the second most consumed quantity was four cubic meters $(18.3 \%)$, and in third place was three cubic meters $(17.6 \%)$. Of the different heating sources, after firewood, the most common source used by those surveyed who used firewood was gas with $25.4 \%$, then electricity with $22.1 \%$, and finally paraffin with $15.7 \%$. On the other hand, among the group of 101 respondents who did not use firewood, the most used energy sources to heat their homes were electricity (33.7\%) and paraffin and gas (29.7\%).

\section{Models' Estimations}

Four models were estimated by way of comparison. These were a) Model 1, consisting of the linear estimation without including covariables; b) Model 2, consisting of the exponential estimation without including covariables; c) Model 3, consisting of the linear estimation including the amount of firewood used by people, people's income level, gender, and the maximum level of education completed

\section{TABLE 2 | Demographic characteristics.}

\begin{tabular}{l} 
Variable \\
\hline Income level (USD) \\
$0-225$ \\
$225-677$ \\
$678-1,248$ \\
$1,249-1,503$ \\
More than 1,503 \\
Education \\
Primary school \\
Secondary school \\
Undergraduate degree \\
Graduate degree \\
Age \\
18-24 years \\
$25-34$ years \\
$35-44$ years \\
$45-54$ years \\
$55-64$ years \\
$65+$ \\
Gender \\
Female \\
Male
\end{tabular}

Number of respondents (\%)

$83(16.5)$
$150(28.8)$
$153(30.4)$
$36(7.2)$
$81(16.1)$
$76(15.0)$
$272(52.2)$
$148(29.4)$
$16(3.2)$
$113(22.5)$
$109(21.7)$
$103(20.5)$
$104(20.7)$
$58(11.5)$
$16(3.2)$
$254(50.5)$
$249(49.5)$

as covariables; and d) Model 4, which was the exponential estimation of the WTP considering the previously mentioned covariables.

In Models 1 and 3, it was expected that the Mean $C+$ and the Median $C^{\star}$ would be the same within each model, whereas in Models 2 and 4 it was expected that the Mean $C+$ and the Median $C^{\star}$ would be different. To determine the significance of the estimators and to make comparisons among them, confidence intervals were created for the measures of well-being. The procedure consisted of estimating the probability distribution of the measures of change in well-being. Krinsky and Robb (1986) proposed a simulation-based method, which was used by Park et al. (1991) to estimate the confidence limits of well-being measures based on contingent valuation models.

In Table 3, the results of the estimation of Models 1 and 2 are presented. Note that in both estimations the payment vector significantly estimates the WTP, being inversely related due to the negative sign of the estimation.

To make a comparison, Models 3 and 4 were estimated, including covariables that could significantly influence people's WTP (Table 4). In both models, covariables were added to the estimation to analyze their behavior, and as can be seen, the payment vector continued to be significant, inversely influencing the WTP, like in Models 1 and 2. Of the covariables included, income was the only one that was significant in the estimation, revealing that the higher the income level, the greater the WTP. The amount of firewood used, the respondents' gender, and the maximum level of education completed were not significant; therefore, it cannot be said that they are related to people's WTP. The non-significance of the covariables explained that the respective coefficients were not the same in Models 3 or 4 .

Table 5 presents the well-being measures considered for each model, as the additional amount of money that they were WTP for a cubic meter of certified dry firewood, i.e., the mean $(\mathrm{C}+)$ or median $\left(C^{\star}\right)$. For Models 1 and 3, being linear, the $C+$ was the same as the $\mathrm{C}^{\star}$. When covariables were not included, the additional WTP for certified dry firewood was 5,564 Chilean pesos (CLP) (8.36 USD), whereas when covariables were included, the WTP increased to 6,098 CLP (9.17 USD). This is because of income in the estimation, where high income levels were represented as a greater WTP. With respect to Models 2 and 4, the WTP is shown, where the $\mathrm{C}+$ is different from the $\mathrm{C}^{*}$; in this case, considering an exponential estimation, the individuals were WTP 7,842 CLP (11.80 USD) on average. When no covariables were included, whereas with the inclusion of covariables the additional individuals' WTP for the use of certified dry firewood was on average 7,983 CLP (12 USD), there was an increase of 141 CLP (0.21 USD) compared to Model 2, with an exchange rate of 665 pesos to 1 United States dollar.

Note that the difference of the $\mathrm{C}+$ was greater between Models 1 and 3, the estimation of which was linear, than between Models 2 and 4, the estimation of which was exponential. In order to compare the models, we used the Akaike information criterion (AIC) (Cavanaugh and Neath, 2019), comparing Model 1 with Model 2 and Model 3 with Model 4 . Table 6 presents the results of the criterion when the models were compared. The comparison of Model 1 with Model 2 revealed that the AIC of Model 2 was smaller than the AIC of Model 1, which is why Model 2 was preferable, i.e., the one used to estimate the WTP with an exponential criterion. When Model 3 was compared with 
TABLE 3 | Estimations of models 1 and 2

Model 1

Response to first and second bids $-0.000246^{\star \star \star}$

(2.87e-05)

$-0.000246^{\star \star \star}$

(2.87e-05)

$\operatorname{Ln}($ bid1)

Ln (bid2)

Constant

Observations $1.367^{\star \star \star}$

(0.148)

312

\section{Model 2}

Response to the log of the first and second bids

$-1.134^{\star \star \star}$

$(0.144)$

$-1.134^{\star \star \star}$

$(0.144)$

$9.679^{\star \star \star}$

(1.222)

312

${ }^{*}, * *$, and ${ }^{* *}$ represent significance at 10,5 , and $1 \%$, respectively.

TABLE 4 | Estimations of models 3 and 4

Model 3

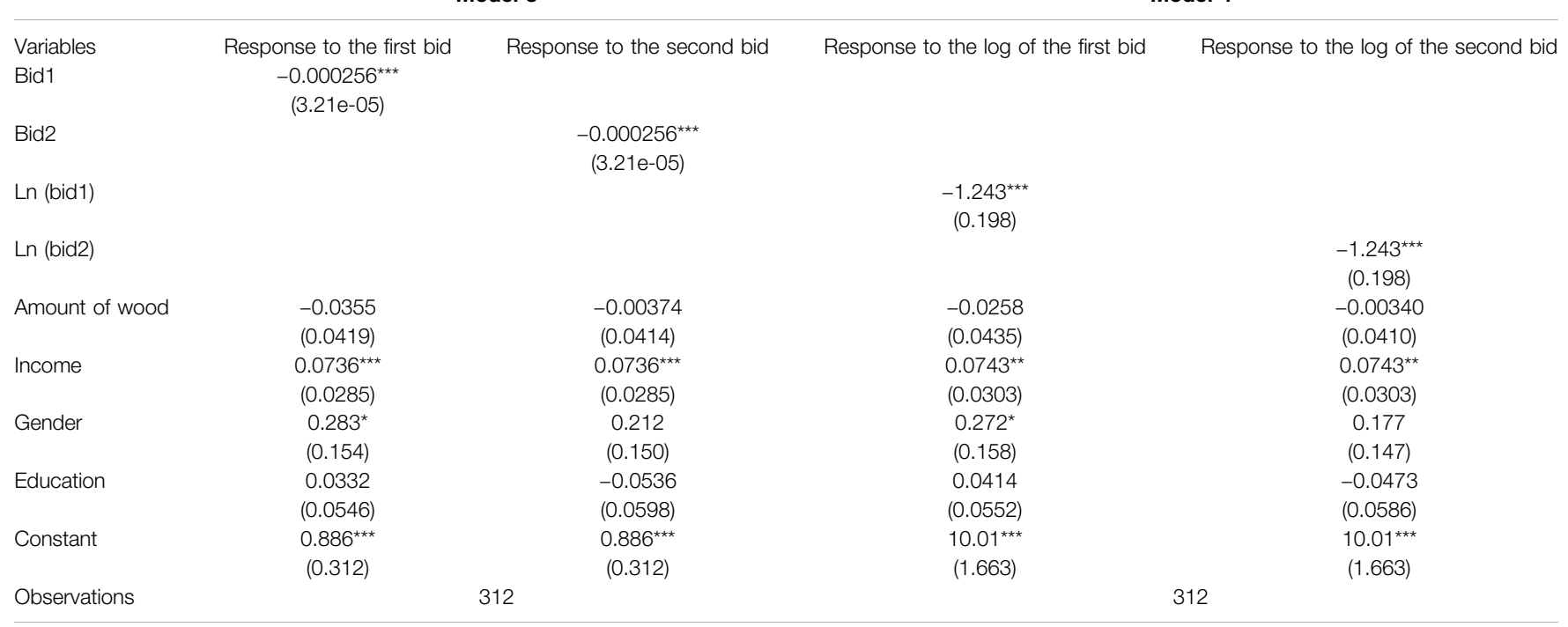

${ }^{*},{ }^{* *}$, and ${ }^{* * *}$ represent significance at 10,5, and 1\%, respectively. Estimations were done in Chilean pesos.

TABLE 5 | WTP for cubic meters of dry wood.

\begin{tabular}{lcccc}
\hline Well-being measure & Model 1 & Model 2 & Model 3 & Model 4 \\
\hline Mean $(\mathrm{C}+)$ & 5,564 & 7,842 & 6,098 & 7,983 \\
Median $\left(C^{\star}\right)$ & & 5,073 & & 5,777 \\
Minimum range C+ & 5,120 & 6,275 & 5,508 & 6,574 \\
Minimum range C* & & 4,612 & & 5,124 \\
Maximum range C+ & \multirow{2}{*}{6,104} & 10,562 & 6,831 & 12,469 \\
Maximum range C* & \multirow{2}{*}{984} & 5,645 & & 6,700 \\
Difference C+ & 4,287 & 1,323 & 5,895 \\
Difference C* & & 1,033 & & 1,576 \\
\hline
\end{tabular}

WTP in CLP. 1 USD = 665 CLP.

Model 4, it was Model 4 that was preferable because the value of the corresponding AIC was smaller.

According to the National Statistics Institute, the population of Talca in 2016 was 227,674 people, and $62 \%$ of the population can be expected to declare a WTP for the use of certified dry firewood. We extrapolated the result to the entire population's WTP, and the average individual's WTP was 12 USD (obtained using Model 4; this value was used as it includes the effect produced by income, unlike Model 2). On average, individuals were willing to pay an additional $26 \%$ per cubic meter over what they currently pay for non-certified firewood.

With a population of 227,674 individuals, assuming families of four individuals, there are 56,919 family groups. Given our sample, only $80 \%$ of these families would be willing to pay a higher value for certified dry firewood, leaving 45,535 families willing to pay a higher price. As the average annual consumption is five cubic meters of wood, and the additional willingness to pay value was $12 \mathrm{USD}$, we obtained an additional annual payment of 60 USD per family, which when multiplied by the number of relevant families $(45,535)$. This gave us an added value to the society equal to $3,415,140$ USD. However, this is just a lower limit society value. If we extrapolate these results to the entire central north and south area of Chile affected by air pollution due to 
TABLE 6 | Akaike information criterion.

\begin{tabular}{lllll}
\hline Criterion & Model 1 & Model 2 & Model 3 & Model 4 \\
\hline AIC & 771.6367 & 768.1609 & 758.1949 & 751.3739 \\
\hline
\end{tabular}

firewood burning, with a total population of over six million, the mentioned value is quite higher.

\section{DISCUSSION}

Our results indicated that individuals are willing to pay an additional 12 USD per cubic meter of certified dry firewood on average, as a means of reducing pollutant emissions and thus avoiding greater environmental restrictions on the use of firewood in home heating stoves. When extrapolating this result, we found that the social valuation reached the amount of $3,415,140$ USD. It is important to mention that this value is almost 5 times higher than that found in a study carried out in the same region approximately 10 years ago (Cerda et al., 2010). At that time, the region did not have environmental restrictions or pollution charges. Therefore, this may be a consequence of the greater pollution in the region and, at the same time, a greater preference or concern for clean air and an increase in the per capita income (Cerda et al., 2010). The positive WTP for clear air matches the situation in the capital Santiago (Cerda et al., 2007) and other cities in the country like Rancagua (García and Álvarez, 2013), where most of the Chilean population is impacted by wood-burning pollution during the winter time in the country.

Although there are studies that indicated that the possibility of charging a higher price for certified forest products is low (Vásquez et al., 2020), our study showed that it is possible when forest products are considered as a source of energy for heating. This could be because people internalize the cost of environmental restrictions on the use of wood stoves and the consequent impact on environmental pollution. In other words, the joint policy measure of certifying firewood, together with restrictions on the use of wet firewood and fines, could help improve air quality. This is even more relevant in the context of a country with energy poverty (Villalobos et al., 2021).

As indicated by Palmieri et al. (2020), literature that evaluates the willingness to pay for firewood is scarce, making it difficult to evaluate the results. In the Italian case, WTP values for eucalyptus firewood have been found to range between 6 EUR (7.3 USD) and 11 EUR (13.8 USD) per quintal, equivalent to 33.1 USD per cubic meter of firewood (Palmieri et al., 2020). While in our case, the average price that Chilean consumers paid 46.4 USD on average for firewood. The lowest price of certified dry firewood is around 57 USD. If we add the estimated additional WTP (12 USD) to the price paid for non-certified firewood, it gives a total value of 58.4 USD, which is slightly higher than the existing minimum price for certified dry firewood. This value corresponds to what individuals would ultimately pay per cubic meter of certified firewood to avoid additional environmental restrictions on the use of the kitchen or wood-burning stoves.
Regarding the determining variables of the WTP for certified dry firewood, it was found that income is a relevant variable, which is consistent with the literature on the valuation of other sources of alternative energy for households (Johnson and Takama, 2012; Kooser, 2014; Streimikiene et al., 2019; Nduka, 2021). However, we did not find statistically significant evidence that education has an influence, contrary to what was found by authors such as Nduka (2021). This could be explained by the fact that in Chile, the choice of fuels to heat homes depends mainly on the income or budget restrictions of families (Jaime et al., 2020).

From an environmental perspective, it is expected that the use of dry firewood will reduce emissions (Dzurenda and Banski, 2019). With such a reduction, the restrictions on the use of stoves for heating could also be reduced, according to the Chilean environmental policy (Jorquera, 2021). Therefore, the fact that people are willing to pay more for certified dry firewood indirectly shows their appreciation for reducing restrictions and improving air quality. This not only occurs with WTP studies based on the attributes of heating stoves (Johnson and Takama, 2012; Maré and Annegarn, 2017) and cooking stoves (Kooser, 2014; Jeuland et al., 2015), but also with different energy sources (Lang et al., 2021), as we have shown in our study with certified dry firewood.

From a public policy point of view, it is important to consider substitutes for firewood as an energy resource for home heating. In this regard, some studies showed that the performance of pellet stoves has the highest achievable goal for solid-fuel stoves (Carvalho et al., 2018). In addition, other more efficient or less polluting alternative sources are being developed (Chung, 2014; Li et al., 2021). However, they are still unaffordable or have higher prices than certified dry firewood for heating. Therefore, considering energy poverty, Chilean household budget restrictions, and the time it takes to adopt new technologies (Martinez-Soto and Jentsch, 2020), the use of certified dry firewood should continue to be promoted as a measure to reduce environmental pollution.

Another alternative measure, which is currently complementary to the promotion of the use of dry firewood, hourly restrictions on wood-burning stoves, and the conversion of heaters, is the improvement of energy efficiency in the construction of houses. This is seen as a good long-term solution because it would reduce the energy demand of homes (Schueftan and González, 2015; Reyes et al., 2019) and thus reduce dependence on firewood for heating. Although it is currently being implemented, its coverage by area is uneven and limited (Jorquera, 2021). Therefore, a comparative costbenefit analysis between the different measures is required to better target the public budget, which could be the subject of future research studies.

An alternative environmental policy would be a geographically differentiated tax on stove use, which would generate the largest net gain, creating substantial welfare gains (Bjørner et al., 2019). But in the case of Chile, taxes cannot be limited to one sector of society, so this proposal is not feasible or easy to implement due to the type of regulation needed. Alternatively, and given the values found in this study, the application of fines or charges according to said amounts 
may encourage people to use less-polluting firewood. However, there is still a credibility problem about whether people will actually pay the fine, given the high transaction cost of this system.

It should be noted that the main limitations of this study are the sample selection biases, which is common in the literature on this subject. In addition, one of the main criticisms of the contingent valuation method is that individuals do not always reveal their preferences or do not understand the hypothetical market (Hausman, 2012). For these reasons, we are aware that the conclusions of this study cannot be overly generalized. However, considering the scarce literature on consumer valuation of certified dry firewood, this study will help to develop environmental policy tools to improve air quality and shows the preferences of users of wood stoves in the face of environmental restrictions on their use of firewood, according to particulate matter emissions. Undoubtedly, this creates the possibility of the application of new public policies in the future.

\section{CONCLUSION}

The authorities do not often have data that allows them to make decisions about goods that are not traded in the regular marketplace, as in the case of society's WTP for air pollution reduction. This study posits an initial idea that can be extended to the rest of the country, mainly to the cities that rank above Talca in PM10 and PM2.5 concentrations. This permits the implementation of public policies focused on reducing these

\section{REFERENCES}

Amegah, A. K., Quansah, R., and Jaakkola, J. J. K. (2014). Household Air Pollution from Solid Fuel Use and Risk of Adverse Pregnancy Outcomes: A Systematic Review and Meta-Analysis of the Empirical Evidence. PLOS ONE 9 (12), e113920. doi:10.1371/journal.pone.0113920

Arnetz, B. B., Arnetz, J., Harkema, J. R., Morishita, M., Slonager, K., Sudan, S., et al. (2020). Neighborhood Air Pollution and Household Environmental Health as it Relates to Respiratory Health and Healthcare Utilization Among Elderly Persons with Asthma. J. Asthma 57 (1), 28-39. doi:10.1080/02770903.2018. 1545856

Arrow, K., Solow, R., Portney, P., Leamer, E., Radner, R., and Schuman, H. (1993). Report of the NOAA Panel on Contingent Valuation. California.

Bangar, V., Mishra, A. K., Jangid, M., and Rajput, P. (2021). Elemental Characteristics and Source-Apportionment of PM2.5 during the Postmonsoon Season in Delhi, India. Front. Sustain. Cities 3 (18). doi:10.3389/ frsc.2021.648551

Bateman, I., and Willis, K. (2002). Valuing Environmental Preferences: Theory and Practice of the Contingent Valuation Method in the US, EU, and Developing Countries. New York: Oxford University Press.

Bjørner, T. B., Brandt, J., Gårn Hansen, L., and Källstrøm, M. N. (2019). Regulation of Air Pollution from wood-burning Stoves. J. Environ. Plann. Manag. 62 (8), 1287-1305. doi:10.1080/09640568.2018.1495065

Boso, À., Oltra, C., and Hofflinger, Á. (2019). Participation in a Programme for Assisted Replacement of wood-burning Stoves in Chile: The Role of Sociodemographic Factors, Evaluation of Air Quality and Risk Perception. Energy Policy 129, 1220-1226. doi:10.1016/j.enpol.2019. 03.038

Cai, Z., and Aguilar, F. X. (2013). Meta-analysis of Consumer's Willingness-To-Pay Premiums for Certified wood Products. Jfe 19 (1), 15-31. doi:10.1016/j.jfe.2012. 06.007 two components in the air, considering that citizens are willing to pay for the use of certified dry firewood, as a way to reduce Ministry of the Environment of Chile restrictions related to the prohibition of wood-burning stoves, the principal source of home heating in many cities.

\section{DATA AVAILABILITY STATEMENT}

The raw data supporting the conclusions of this article will be made available by the authors, without undue reservation.

\section{ETHICS STATEMENT}

Ethical review and approval was not required for the study on human participants in accordance with the local legislation and institutional requirements. The patients/participants provided their written informed consent to participate in this study.

\section{AUTHOR CONTRIBUTIONS}

Conceptualization: AC and LG; Methodology: AC and LG Software and Validation; Writing-review and editing final manuscript: AC and LG; Initial Data Analysis and First Draft: $\mathrm{RL}, \mathrm{PM}$, and MM.

Carvalho, R. L., Vicente, E. D., Tarelho, L. A. C., and Jensen, O. M. (2018). Wood Stove Combustion Air Retrofits: A Low Cost Way to Increase Energy Savings in Dwellings. Energy and Buildings 164, 140-152. doi:10.1016/j.enbuild.2018.01.002

Cavanaugh, J. E., and Neath, A. A. (2019). The Akaike Information Criterion: Background, Derivation, Properties, Application, Interpretation, and Refinements. Wires Comput. Stat. 11 (3), e1460. doi:10.1002/wics.1460

Cerda, A. A., Rojas, J., and García, L. Y. (2007). Disposición a pagar por un mejoramiento en la calidad ambiental en el Gran Santiago, Chile. Lecturas de Economía 67, 143-160. doi:10.17533/udea.le.n67

Cerda, A. A., García, L. Y., Bahamondez, A., and Poblete, V. (2010). Comparison of Willingness to Pay (WTP) for an Improvement in Air Quality between Users and Nonusers of Firewood in the City of Talca (Chile). Lecturas de Economía 72, 195-211. doi:10.17533/udea.le.n72

Cerda, A. A., Garcia, L. Y., Pastén, R. A., Damino, I. A., and Diaz, M. T. (2014). The Effects of Visual Information on Willingness to Pay for a Recreational Site Improvement in Chile. Innovar 24 (53), 141-148. doi:10.15446/innovar. v24n53.43921

Chung, J. N. (2014). A Theoretical Study of Two Novel Concept Systems for Maximum Thermal-Chemical Conversion of Biomass to Hydrogen. Front. Energ. Res. 1 (12). doi:10.3389/fenrg.2013.00012

Cooper, J., and Hellerstein, D. (1994). CVM Software. Washington, DC: Resource Technology División, USDA. doi:10.1142/9789814350938_0020

Cooper, J. C. (1993). Optimal Bid Selection for Dichotomous Choice Contingent Valuation Surveys. J. Environ. Econ. Manag. 24, 25-40. doi:10.1006/jeem.1993.1002

Cuccia, T. (2020). "Contingent Valuation," in Handbook of Cultural Economics. Third Edition (Cheltenham: Edward Elgar Publishing). doi:10.4337/ 9781788975803

Dixon, J. A., and Hufschmidt, M. M. (1986). Economic Valuation Techniques for the Enviroment. Baltimore: The Johns Hopkins University Press.

Dzurenda, L., and Banski, A. (2019). The Effect of Firewood Moisture Content on the Atmospheric Thermal Load by Flue Gases Emitted by a Boiler. Sustainability 11 (1), 284. doi:10.3390/su11010284 
Fattahi Ardakani, A., Alavi, C., and Arab, M. (2017). The Comparison of Discrete Payment Vehicle Methods (Dichotomous Choice) in Improving the Quality of the Environment. Int. J. Environ. Sci. Technol. 14 (7), 1409-1418. doi:10.1007/ s13762-017-1246-x

Fleisch, A. F., Rokoff, L. B., Garshick, E., Grady, S. T., Chipman, J. W., Baker, E. R., et al. (2020). Residential wood Stove Use and Indoor Exposure to PM2.5 and its Components in Northern New England. J. Expo. Sci. Environ. Epidemiol. 30 (2), 350-361. doi:10.1038/s41370-019-0151-4

Freeman, A., III, Herriges, J., and Kling, C. (2014a). The Measurement of Environmental and Eesource Values. New York: Routledge. doi:10.4324/ 9781315780917

Freeman, M., III, Herriges, J., and Kling, C. (2014b). The Measurement of Environmental and Resource Values. Washington D.C: Resources for the Future. doi:10.4324/9781315780917

García, L., and Álvarez, P. (2013). Valoración económica de una mejora en la calidad del aire en la ciudad de Rancagua, Chile. Rev. Interam Ambient Tur., 108-119. doi:10.4067/riatvol9iss2pp108-119250718-235X

Haab, T. C., and McConnell, K. E. (2002). Valuing Environmental and Natural Resources: The Econometrics of Non-market Valuation. MA: Edward Elgar Publishing. doi:10.4337/9781843765431

Hanemann, M., Loomis, J., and Kanninen, B. (1991). Statistical Efficiency of Double-Bounded Dichotomous Choice Contingent Valuation. Am. J. Agric. Econ. 73 (74), 1255-1263. doi:10.2307/1242453

Hanemann, M. (1984). Welfare Evaluations in Contingent Valuation Experiments with Discrete Responses. Am. J. Agr Econ. 66 (3), 222-241. doi:10.2307/1240800

Hausman, J. (2012). Contingent Valuation: From Dubious to Hopeless. J. Econ. Perspect. 26 (4), 43-56. doi:10.1257/jep.26.4.43

Hime, N., Marks, G., and Cowie, C. (2018). A Comparison of the Health Effects of Ambient Particulate Matter Air Pollution from Five Emission Sources. Ijerph 15 (6), 1206. doi:10.3390/ijerph15061206

IQAir (2020). World's Most Polluted Countries 2020 (PM2.5). [Online]. Available: www.iqair.com/world-most-polluted-countries (Accessed april 27, 2021).

Ivehammar, P. (2009). The Payment Vehicle Used in CV Studies of Environmental Goods Does Matter. J. Agr Resour. Econ. 34 (3), 450-463. https://www.jstor.org/ stable/41548427

Jaime, M. M., Chávez, C., and Gómez, W. (2020). Fuel Choices and Fuelwood Use for Residential Heating and Cooking in Urban Areas of central-southern Chile: The Role of Prices, Income, and the Availability of Energy Sources and Technology. Resource Energ. Econ. 60, 101125. doi:10.1016/j.reseneeco.2019.101125

James, D. (1994). Economic Valuation Techniques. Dordrecht: Springer Netherlands. doi:10.1007/978-94-015-8384-8

Jeuland, M. A., Bhojvaid, V., Kar, A., Lewis, J. J., Patange, O., Pattanayak, S. K., et al. (2015). Preferences for Improved cook Stoves: Evidence from Rural Villages in north India. Energ. Econ. 52, 287-298. doi:10.1016/j.eneco.2015.11.010

Johnson, F. X., and Takama, T. (2012). "Economics of Modern and Traditional Bioenergy in African Households: Consumer Choices for Cook Stoves," in Bioenergy for Sustainable Development in Africa. Editors R. Janssen and D. Rutz (Dordrecht: Springer Netherlands), 375-388. doi:10.1007/978-94-007-2181-4_30

Jorquera, H. (2021). Air Quality Management in Chile: Effectiveness of PM2.5 Regulations. Urban Clim. 35, 100764. doi:10.1016/j.uclim.2020.100764

Kanninen, B. J. (1993). Optimal Experimental Design for Double-Bounded Dichotomous Choice Contingent Valuation. Land Econ. 69 (2), 138-146. doi: $10.2307 / 3146514$

Kooser, S. H. (2014). Clean Cooking: The Value of Clean Cookstoves in Ethiopia. J. Environ. Resource Econ. Colby 1 (1), 3.

Krinsky, I., and Robb, A. L. (1986). On Approximating the Statistical Properties of Elasticities. The Review of Economics and Statistics, 715-719. doi:10.2307/ 1924536

Lang, G., Farsi, M., Lanz, B., and Weber, S. (2021). Energy Efficiency and Heating Technology Investments: Manipulating Financial Information in a Discrete Choice experiment. Resource Energ. Econ. 64, 101231. doi:10.1016/j.reseneeco. 2021.101231

Lee, C.-Y., and Heo, H. (2016). Estimating Willingness to Pay for Renewable Energy in South Korea Using the Contingent Valuation Method. Energy Policy 94, 150-156. doi:10.1016/j.enpol.2016.03.051

Li, Q., Li, J., Huang, Z., Fan, F., and Teng, W. (2021). A Real-Time Electricity Price Decision Model for Demand Side Management in Wind Power Heating Mode. Front. Energ. Res. 9 (16). doi:10.3389/fenrg.2021.634603
Loomis, J., and Ekstrand, E. (1997). Economic Benefits of Critical Habitat for the Mexican Spotted Owl: A Scope Test Using a Multiple-Bounded Contingent Valuation Survey. J. Agr Resour. Econ. 22 (2), 356-366.

Mardones, C., and Cornejo, N. (2020). Ex - post Evaluation of a Program to Reduce Critical Episodes Due to Air Pollution in Southern Chile. Environ. Impact Assess. Rev. 80, 106334. doi:10.1016/j.eiar.2019.106334

Mardones, C. (2021). Ex-post Evaluation and Cost-Benefit Analysis of a Heater Replacement Program Implemented in Southern Chile. Energy 227, 120484. doi:10.1016/j.energy.2021.120484

Maré, M., and Annegarn, H. J. (2017). The Use of Willingness to Pay in Determining Customer Preferences for Improved Flame-Based Cookstove Features in Two South African Study Areas. Soc. Marketing Q. 23 (4), 335-353. doi:10.1177/1524500417732773

Martinez-Soto, A., and Jentsch, M. F. (2020). A Transferable Energy Model for Determining the Future Energy Demand and its Uncertainty in a Country's Residential Sector. Building Res. Inf. 48 (6), 587-612. doi:10.1080/09613218. 2019.1692188

Martinez-Soto, A., Saldias-Lagos, Y., Marincioni, V., and Nix, E. (2020). Affordable, Energy-Efficient Housing Design for Chile: Achieving Passivhaus Standard with the Chilean State Housing Subsidy. Appl. Sci. 10 (21), 7390. doi:10.3390/app10217390

Ministerio de Medio Ambiente (2017). Tercera Encuesta Nacional de Medio Ambiente. Sistema de Información Nacional de Calidad del Aire. [Online]. Gobierno de Chile. Available: https://mma.gob.cl/tercera-encuesta-nacionaldel-medio-ambiente/ (Accessed april 27, 2021).

Nduka, E. (2021). How to Get Rural Households Out of Energy Poverty in Nigeria: A Contingent Valuation. Energ Policy 149, 112072. doi:10.1016/j.enpol.2020. 112072

Obeng, E. A., and Aguilar, F. X. (2021). Willingness-to-pay for Restoration of Water Quality Services across Geo-Political Boundaries. Curr. Res. Environ. Sustainability 3, 100037. doi:10.1016/j.crsust.2021.100037

Oerlemans, L. A. G., Chan, K.-Y., and Volschenk, J. (2016). Willingness to Pay for green Electricity: A Review of the Contingent Valuation Literature and its Sources of Error. Renew. Sust. Energ. Rev. 66, 875-885. doi:10.1016/j.rser.2016.08.054

Ostro, B., Sánchez, J. M., Aranda, C., and Eskeland, G. S. (1996). Air Pollution and Mortality: Results from a Study of Santiago, Chile. J. Expo. Anal. Environ. Epidemiol. 6 (1), 97-114.

Palmieri, N., Suardi, A., and Pari, L. (2020). Italian Consumers' Willingness to Pay for Eucalyptus Firewood. Sustainability 12 (7), 2629-2714. doi:10.3390/ sul2072629

Park, T., Loomis, J., and Creel, M. (1991). Confidence Intervals for Evaluating Benefits Estimates from Dichotomous Choice Contingent Valuation Studies. Land Econ. 67, 63-73. doi:10.2307/3146486

Quinteros, M., Ossa, X., Blazquez, C., Rosas, F., Cardenas, J., Bartington, S., et al. (2019). Effect of Residential wood-burning Air Pollution on Pre-eclampsia in Temuco, Chile: a Retrospective Cohort Study. Environ. Epidemiol. 3, 320. doi:10.1097/01.EE9.0000609508.03524.c1

Reyes, R., Schueftan, A., Ruiz, C., and González, A. D. (2019). Controlling Air Pollution in a Context of High Energy Poverty Levels in Southern Chile: Clean Air but Colder Houses? Energy Policy 124, 301-311. doi:10.1016/j.enpol.2018. 10.022

Romieu, I. G. N., Gouveia, N., de Leon, A. P., Junger, W., Vera, J., et al.HEI Health Review Committee (2012). Multicity Study of Air Pollution and Mortality in Latin America (The ESCALA Study). Res. Rep. Health Eff. Inst. 171, 5-86.

Schueftan, A., and González, A. D. (2015). Proposals to Enhance thermal Efficiency Programs and Air Pollution Control in South-central Chile. Energy Policy 79, 48-57. doi:10.1016/j.enpol.2015.01.008

Schueftan, A., Sommerhoff, J., and González, A. D. (2016). Firewood Demand and Energy Policy in South-central Chile. Energ. Sust. Dev. 33, 26-35. doi:10.1016/j. esd.2016.04.004

Segerson, K. (2017). "Valuing Environmental Goods and Services: An Economic Perspective," in A Primer on Nonmarket Valuation. The Economics of Nonmarket Goods and Resources. Editors P. Champ, K. Boyle, and T. Brown (Dordrecht: Springer).

Shi, Z., Vu, T., Kotthaus, S., Harrison, R. M., Grimmond, S., Yue, S., et al. (2019). Introduction to the Special Issue "In-Depth Study of Air Pollution Sources and Processes within Beijing and its Surrounding Region (APHH-Beijing)". Atmos. Chem. Phys. 19 (11), 7519-7546. doi:10.5194/acp-19-7519-2019 
Sinha, J., and Kumar, N. (2019). Mortality and Air Pollution Effects of Air Quality Interventions in Delhi and Beijing. Front. Environ. Sci. 7 (15). doi:10.3389/ fenvs.2019.00015

Streimikiene, D., Balezentis, T., Alisauskaite-Seskiene, I., Stankuniene, G., and Simanaviciene, Z. (2019). A Review of Willingness to Pay Studies for Climate Change Mitigation in the Energy Sector. Energies 12 (8), 1481. doi:10.3390/en12081481

Vásquez, F., Cerda, A., and Orrego, S. (2007). Valoración económica del ambiente. Fundamentos Económicos, Econométricos y Aplicaciones. Buenos Aires, Argentina: Thomson Learning.

Vásquez, F., Barrientos, M., Castillo, Á., Herrera, I., and Ponce Oliva, R. D. (2020). Firewood Certification Programs: Key Attributes and Policy Implications. Energ Policy 137, 111160. doi:10.1016/j.enpol.2019.111160

Villalobos, C., Chávez, C., and Uribe, A. (2021). Energy Poverty Measures and the Identification of the Energy Poor: A Comparison between the Utilitarian and Capability-Based Approaches in Chile. Energy Policy 152, 112146. doi:10.1016/ j.enpol.2021.112146
Xie, B.-C., Zhao, W., Yin, Z.-L., and Xie, P. (2019). How Much Will the Residents Pay for Clean Energy? Empirical Study Using the Double Bound Dichotomous Choice Method for Tianjin, China. J. Clean. Prod. 241, 118208. doi:10.1016/j. jclepro.2019.118208

Conflict of Interest: The authors declare that the research was conducted in the absence of any commercial or financial relationships that could be construed as a potential conflict of interest.

Copyright (C) 2021 García, Cerda, Lagos, Muñoz and Muñoz. This is an open-access article distributed under the terms of the Creative Commons Attribution License (CC $B Y)$. The use, distribution or reproduction in other forums is permitted, provided the original author(s) and the copyright owner(s) are credited and that the original publication in this journal is cited, in accordance with accepted academic practice. No use, distribution or reproduction is permitted which does not comply with these terms. 